\title{
A Study on Phytochemical Evaluation of Ardra and Shushka Dosage Formsof Eclipta Alba Hassk. (Bhringaraj) Panchanga According to Sharangdhar Samhita
}

\author{
Shekokar S. S. , Nayak S. U.* \\ Ph.D. (scholar), TMV, Pune, \\ *(Supervisor), TMV, Pune
}

\begin{abstract}
:
Pharmacological properties of the plant drug depend on their phytochemical constitution. Sharangadharacharya has quoted to use ardra dravya always dviguna (twice) in quantity to shushka dravya as there may be changes in properties or quantity of the phytochemical constituents.

Aims and objectivesare to evaluate physicochemical \& phytochemical properties of ardraandshushka dosage forms of Bhrungaraj - Eclipta alba Hassk.panchanga.

Methods- Ardra and shushka dosage forms of self-collected Bhrungaraj panchanga were prepared as follows-1) swaras (ardra/wet form), 2) anukalpa swaras (ardra/wet form), 3) shushka churna (dry form) and 4) tablet form (shushka/dry form). Various phytochemical tests for solid and liquid forms as per applicability - Foreign matter test, Extractive values, ash values, HPLC, HPTLC, Spectrophotometry, Atomic absorption Spectrophotometry,etc.

Observation and results- All the tests like extractive values, ash values, and others were having equal results in all dosage forms but atomic absorption spectrophotometry showed that Iron content was highest in anukalpa swaras ghan vati(dry form)- 3060 ppm, and comparatively very less in spray dried tablet (370.137 ppm), fresh swaras (108.0 ppm), and churna (211.84 ppm). Similarly, content of wedelolactone was maximum in churna(dry form) and minimum in fresh swaras (wet form).
\end{abstract}

Key words: Ardra, shushka, guru, tikshna, phytochemical and physicochemical,

\section{Introduction}

Pharmacological properties of the plant drug are based on the different phytochemical constituents ${ }^{1}$ present within these plants and these phytochemical constituents produce definite physiological or pharmacological action on the human body ${ }^{2}$.

The chemical composition of the plant drug is dependent on species identity and harvest time, collection time, maturity of plant, soil composition, altitude, actual climate, processing, storage conditions. The transformation, processing and degradation may cause changes in the phytochemical of compounds $^{3}$.Ayurveda has considered all these factors since ancient times and accordingly formularies has been established which are based on some basic principles for the treatment as well as formulation of medicine. One such ayurvedic formulary is Sharangdhar Samhita in which Sharangadharacharya ${ }^{4}$ has described to use shushka dravya (dry drug) which is freshly collected from plant source and recently dried (not to use old dravya as shushka dravya) in the preparation of medicine. Similarly, when there is reference 


\section{Shekokar S. S., International Journal of Ayurvedic\& Herbal Medicine 8(3) May.-June. 2018 (3223-3234)}

of ardra dravya (fresh plant drug) always use freshly collected samples from plant source and it is also stated to use ardra dravya twice in quantity to that of shushka dravya. This is because there may be some difference in the properties or quantity of the phytochemical constituents present in the drug in shushka and ardra avastha (condition).

Therefore, a study was planned to understand this concept to evaluate the difference in physicochemical and phytochemical properties in ardra and shushka dravya with the help of various physicochemical and phytochemical analytical tests.

Eclipta alba is an annual herbaceous plant, commonly found and having a long history of traditional medicinal uses. A wide range of chemical compounds including coumestans,alkaloids, thiopenes, flavonoids, polyacetylenes, triterpenes ${ }^{5,6,7,8}$ and their glycosides have been isolated from this species. High therapeutic and medicinal values are due to its chemical composition with wedelolactone, desmethylwedelolactone, 14-hepatocosanol, luteolin-7-0-glucoside, alkaloids and polypeptides as principle components ${ }^{9}$.Because of its varied medicinal values, it has great commercial demand which calls for further investigation at the bimolecular level. For the same reason, this species needs prime attention for its future cultivation and conservation ${ }^{10}$. Bhavaprakash Samhita ${ }^{11}$ has described that Bhrungaraj is especially effective in yakrut vikruti, yakrut vruddhi, pandu, kamala, shotha and other diseases related to yakrut. Dhanvantari Nighantu ${ }^{12}$, Raj Nighantu ${ }^{13}$,Kaiyyadev Nighantu ${ }^{14}$ has also described that Bhrungaraj is indicated in pandu, shotha, kamala and Vaghbhata advocated its consumption for one month to have rasayana effect. SoBhrungaraj was selected for the Shushka and ardra dosage forms of Bhrungaraj. Aims and objectives: To study physicochemical and phytochemical propertiesofshushka and ardra dosage forms through physicochemical and phytochemical properties tests and to understand the difference in chemical constituents of ardra and shushka forms.

\section{Material and methods:}

Samples of Bhrungaraj were self-collected gathered from its natural habitat from Naginaghat area of Nanded. The plants were botanically identified ${ }^{15}$ and authenticated by local botanists of Botany Department, Department of Botany, Nanded Education Society's (NES) Science College, Nanded and confirmed as Eclipta alba Hassk.

\section{Place of work:}

Drug testing laboratory, Government Ayurved and Unani Pharmacy, Nanded and Qualichem laboratories, Nagpur.

\section{Organoleptic andmicroscopic examination:}

The sample of Bhrungaraj was examined for all its organoleptic characters and microscopic examination ${ }^{16}$.

\section{Preparation of study drug samples for physicochemical study}

For the evaluation of physicochemical and phytochemical properties of ardra and shushka dosage forms of Bhrungaraj panchanga four different dosage forms were prepared such as -

1. swaras (ardra/wet form),

2. anukalpa swaras (ardra/wet form),

3. shushka churna (dry form) and

4. tablet form (shushka/dry form).

For this purpose, different dosage forms used were -

1. Swaras, (ardra/wet form)

2. Spray dried swaras ghan vati, (ardra/wet form)

3. Anukalpa swaras (shushka/dry form)and

4. Ghan vati of anukalpa swaras(shushka/dry form) 


\section{Procedure for preparation of the above dosage forms:}

1. Procedure for preparation of swaras:The plant samples free from any pest, disease or decay and fresh were collected, cleaned and then crushed to paste like form which was tightly held in clean piece of cloth and the Bhrungaraj swaras was obtained after filtering through the cloth as per procedure described in Sharangdhar samhita ${ }^{17}$.

2. Procedure for preparation of anukalpa swaras: Dried plant material was grinded to prepare churna and to one part of churna water was added twice in quantity (dviguna). The filtrate was kept overnight and was smashed with hands and then filtered with clean cloth this filtrate was used as Anukalpa swaras (nishoshit swaras/ swaras from shushka dravya) ${ }^{18,19}$.

3. Procedure for preparation of ghan vati of anukalpa swaras: As per the method described in Siddha sara sangraha ${ }^{20}$ churna was taken once in quantity and water was added four times to it. The mixture was boiled until $1 / 4^{\text {th }}$ of the mixture was left. This was then cooled and filtered with clean cloth and then the filtrate was kept for boiling again until it became thick paste and then it was cooled and passed to tablet making machine for preparation of tablets of $500 \mathrm{mg}$ eachnamed as anukalpa swaras ghan vati. Tablets were obtained and dried, packing of tablets was done under hygienic condition.

4. Procedure for preparation of dried form of swaras (spray dry swaras ghan vati): The spray drying procedure of fresh swaraswas conducted in five steps as per the standard operating procedure ${ }^{21}$ a).Bhrungaraj swaras was concentrated by heating and then introduced into the spray dryer. b).Evaporation of the introduced swaras was started using rotatory atomizer by exposing the concentrated swaras spray with the heated air. c). After atomization the atomized liquid was exposed to hot air at vacuum and here evaporation process was completed along with evaporation of water droplets. d). Temperature was maintained and complete moisture was evaporatedand resultant particles obtained in the form of irregularly shaped porous spheres.e). The obtained powdered particles were separated from the bottom of the instrument. Ghan vati of this spray dry powder was preparedand named as spray dry swarasghan vati.Tablets were obtained and dried, packing of tablets was done under hygienic condition.

\section{Methodology for physicochemical studies:}

To evaluate the difference in physicochemical and phytochemical properties of shushka (dry) and ardra (wet) dosage forms different tests were applied as per applicability.

\section{Tests applied for solid form of drug}

1. Physicochemical tests

2. Phytochemical tests

3. Chromatographic analysis

4. Spectrophotometry UV

5. Atomic-absorption Spectrophotometry

\section{Tests applied for liquid form of drug}

1. Specific gravity

2. Viscosity

3. Spectrophotometry

4. Chromatographic analysis

5. Atomic-absorption spectrophotometry

\section{Determination of Foreign matter}

The collected raw material of drug sample was spread on white paper and foreign matter was separated, weight was taken and the percentage of foreign matter present was calculated ${ }^{22}$.

pH Value

Determination of $\mathbf{p H}-1$ gm of powdered drug was extracted in $100 \mathrm{ml}$ of distilled water and the $\mathrm{pH}$ was measured using previously calibrated $\mathrm{pH}$ meter $^{23}$.

Determination of swelling index- 1 gm of powder was soaked in $25 \mathrm{ml}$ of water in a glass topped measuring cylinder was shaken vigorously and kept standing for 3 hours, then the height of churna was calculated and difference calculated from initial height reading ${ }^{24}$. 


\section{Shekokar S. S., International Journal of Ayurvedic\& Herbal Medicine 8(3) May.-June. 2018 (3223-3234)}

Determination of foaming index (F.I.)-1\% water extract of Bhringaraj churna was diluted to $100 \mathrm{ml}$, this solution was then added to 10 stoppered test tubes as $1 \mathrm{ml}, 2 \mathrm{ml}, 3 \mathrm{ml}$, etc. up to $10 \mathrm{ml}$ and made to $10 \mathrm{ml}$ each by adding distilled water and shaken vigorously, height of foam was measured as FI = 100/a Where $\mathrm{a}=$ the volume in $\mathrm{ml}$ of decoction ${ }^{25}$.

Determination of moisture content / loss on drying -The instrument Halogen moisture content analyzer was switched on and initially weighed sample was added.After pressing the start key the drying process was started.At the end of the process drying temperature, weight after drying, total drying time and $\%$ of moisture content displayed ${ }^{26}$.

Digital Colorimetry-5\% of water extract of Bhrungaraj was used for colorimetry analysis with reference to distilled water.The wavelength adjusted as per the color of solution. The sample of swaras and anukalpa swaras were placed in cuvette and the readings were taken ${ }^{27}$.

Determination of Extractives - 5\% alcohol extract of the Bhrungaraj churnawas prepared in shaker machine by shaking for six hours and standing for $18 \mathrm{hrs}$. The extract was filtered in previously weighed empty petri dish and was allowed to evaporate till complete drying and weight taken. The difference in weight and the percentage was calculated. Same procedure applied to anothersolvents ${ }^{28}$.

Determination of total ash value- $1 \mathrm{~g}$ of powdered sample taken in a previously weighed empty platinum crucible was burnt to ash.The difference in weight and \% was calculated. Similarly,acid insoluble ash and water-soluble ash was determined as per method described in $\mathrm{API}^{29}$.

Spectrophotometry- In UV visible double beam scanning spectrophotometer,5\% water extract of Bhrungarajpowder was used for analysis. The wavelength (800-400, 400-200 nm), scanning, speed; absorbance, etc. were set and reference was taken as water of the compartment, scanning was started and the specific absorption spectrum was displayed on the monitor. The numbers of peaks, their absorbance of respective wavelength was recorded.

Wedelolactone, Ecliptaalbasaponin I and II were used as standards for comparison ${ }^{30}$.

Thin Layer Chromatography analysis - 5\% extract of Bhrungaraj samples were prepared by using different solvents. The cleaned glass plates were coated with Silica Gel $-\mathrm{G}$ slurry using the spreading device toa thickness of $0.25 \mathrm{~mm}$. The plates were dried and activated. Thespots of samples were applied with the help of a micro capillary and dried ${ }^{31}$.

The chromatography chambers were activated by the saturation of fumeso the solvent mixtures used as mobile phaseevaluated on the basis of the nature of the components by trial and error.Ascending technique was used and the level of the solventflow was marked and the observed spots were marked with needle in daylight and ultraviolet light. The retention factors(Rf value) were calculated as described in the observation and results.

Atomic absorption Spectrophotometry- The water extracts of all dosage forms were prepared,instrument was calibrated, the standard solutions were introduced into the flame and then the extracts were introduced, the steady readings were recorded.The apparatus was washed through with water after every trial. The concentrations of the elements were determined from the calibration curve ${ }^{32}$.

High performance thin layer chromatography (HPTLC)- The methanolic extract of all dosage forms wereprepared.Wedelolactone, Ecliptaalbasaponin-I and Ecliptaalbasaponin-II were used as marker compounds; these markers were dissolved in methanol at a concentration of $1 \mathrm{mg} / \mathrm{ml}$. Samples were applied above the lower edge of the plate and points were marked with a pencil.A twin trough chamber was filled with mobile phase solvent mixture and was left for saturation. The plates were kept in the chamber and removed whenthe mobile phase travelled the distance of $6 \mathrm{~cm}$ and dried. After that derivatization reagent was sprayed and the plates were visualized and chromatograms were observed and compared with monograph and standards used ${ }^{33}$. 
Shekokar S. S., International Journal of Ayurvedic\& Herbal Medicine 8(3) May.-June. 2018 (3223-3234) High performance liquid chromatography (HPLC) - Luna 5-micron $\mathrm{NH}_{2} 100$ angstrom column was used for performing reverse phase high performance liquid chromatography using the above prepared dosage form sample extracts prepared previously and wedelolactone, Ecliptaalbasaponin I and II were used as standards ${ }^{34}$.

\section{Phytochemical analysis}

Qualitative phytochemical analysis of the extracts was carried out such as-
1) Test for tannins ${ }^{35}$,
6) Test for sterol ${ }^{40}$
2) Test for resins ${ }^{36}$
7) Test for amino acid ${ }^{41}$
3) Test for saponins ${ }^{37}$
8) Test for alkaloids ${ }^{42}$
4) Test for glycosides/carbohydrates ${ }^{38}$
9)Test for starchnon-reducing polysaccharides ${ }^{43}$
5) Test for proteins ${ }^{39}$

\section{Observation and Results:}

\section{Macroscopic and Microscopic examination}

The macroscopic examination of Bhrungaraj entire fresh plant as shown in figures 1-6.

\section{Organoleptic characters:}

Table 1: Organoleptic characters of Bhrungaraj

\begin{tabular}{|l|l|l|l|}
\hline Sr no. & Characters & Bhrungaraj powder & Spray dry powder \\
\hline 1 & Colour & Dark green & Dark green \\
\hline 2 & Odour & Mild & Mild \\
\hline 3. & Taste & Sour and bitter & Sour and bitter \\
\hline 4. & Structure & Smooth & Smooth \\
\hline 5. & Colour of water extract & Dark green & Dark green \\
\hline
\end{tabular}

Physicochemical standardization

Table 2: Test for determination of foreign matter

\begin{tabular}{|l|l|r|}
\hline Samples & Weight of foreign matter collected & Percentage \\
\hline Entireplant (dried) & $54 \mathrm{gms}$ & $1.5 \% \mathrm{~W} / \mathrm{W}$ \\
\hline
\end{tabular}

Table 3: pH values

\begin{tabular}{|l|l|l|}
\hline Samples & $\mathrm{pH}$ & $\mathrm{pH}$ after 24 hours \\
\hline Bhrungaraj Churna & 4.2 & 4.2 \\
\hline Bhrungaraj Swaras & 4.1 & 4.1 \\
\hline Bhrungaraj Tablet & 4.2 & 4.2 \\
\hline Bhrungaraj Anukalpa Swaras & 4 & 4 \\
\hline
\end{tabular}

Table 4:Swelling index of Bhrungaraj churna

\begin{tabular}{|c|c|c|}
\hline Observation & Bhrungaraj Churna & Spray Dry Drug \\
\hline Mean & 1.03 & 1.03 \\
\hline
\end{tabular}

Table 5: Moisture content

\begin{tabular}{|c|c|c|c|c|c|}
\hline Sr. No. & Sample & Initial Wt in gms & Wt. Afterwards (gms) & Loss (In Gm) & \% M.C. \\
\hline 1. & Bhrungaraj churna & 1.004 & 0.988 & 0.016 & 1.5936 \\
\hline 2. & Spray Dry Powder & 1.009 & 0.992 & 0.017 & 1.6848 \\
\hline
\end{tabular}


Shekokar S. S., International Journal of Ayurvedic\& Herbal Medicine 8(3) May.-June. 2018 (3223-3234)

Table 6: Foaming index

\begin{tabular}{|c|c|c|c|}
\hline Sr. No. & Swaras & Spray Dry Drug & Tablet \\
\hline Foaming Index & $<100$ & $<100$ & $<100$ \\
\hline
\end{tabular}

Table 7: Optical density at $(670 \mathrm{~nm})$ (Colorimetry analysis)

\begin{tabular}{|l|l|}
\hline Sample & Optical density \\
\hline Swaras (partial free) & 0.41 \\
\hline Anukalpa Swaras (partial free) & 0.25 \\
\hline
\end{tabular}

Table 8: Extractive values of Bhrungaraj churna

\begin{tabular}{|l|l|l|}
\hline Type of extractives & Bhrungaraj Churna & Bhrungaraj spray dry drug \\
\hline Alcohol soluble & 9.8 & 12.5 \\
\hline Water soluble & 26.00 & 26.6 \\
\hline Methanol soluble & 14.7 & 19.63 \\
\hline Petroleum ether & 2.80 & 2.8666 \\
\hline Benzene soluble & 13.0 & 13.6 \\
\hline Chloroform soluble & 10.79 & 11.4 \\
\hline Ethanol soluble & 9.5 & 10.6 \\
\hline
\end{tabular}

Table 9: Ash values

\begin{tabular}{|l|l|l|}
\hline Observation & Bhrungaraj Churna & Bhrungaraj spray dry drug \\
\hline Total ash & 14.4 & 4.4 \\
\hline Acid insoluble & 3.06 & 1.7333 \\
\hline Water soluble & 12.4 & 3.2 \\
\hline
\end{tabular}

Tests applied to Bhrungaraj swaras

Table 10: Refractive indices

\begin{tabular}{|c|c|c|}
\hline Samples & Fresh swaras & Anukalpa Swaras \\
\hline RI & 1.3434 & 1.3312 \\
\hline
\end{tabular}

Table 11: Spectrophotometry analysis

\begin{tabular}{|l|l|l|}
\hline Sample & Wavelength in $\mathrm{nm}$ & Absorbance \\
\hline Fresh swaras & $215.0,330.0$ & $1.76,1.00$ \\
\hline Churna & $215.0,330.0$ & $1.76,1.40$ \\
\hline Spray dry ghan vati & $390.0,330.0$ & $3.50,2.50$ \\
\hline Anukalpa swaras ghan vati & $230.0,330.0$ & $2.270,1.15$ \\
\hline
\end{tabular}

Table 12: Thin layer chromatographic values of Bhrungaraj churna

Rf values:

\begin{tabular}{|c|c|c|c|c|}
\hline \multicolumn{2}{|l|}{ R† values: } & \multicolumn{3}{|c|}{ S.F. $=15.8 \mathrm{~cm}$} \\
\hline Extract & Mobile phase & I/ Vis & Under UV light & In Iodine chamber \\
\hline $\begin{array}{l}\text { Petroleum } \\
\text { ether }\end{array}$ & $\begin{array}{l}\text { Mobile phase used- Benzene: } \\
\text { Chloroform }\end{array}$ & 0.02 & -- & -- \\
\hline Benzene & Chloroform: Ethanol ((9.5:0.5) & 0.8 & 0.53 & 0.42 \\
\hline Chloroform & Chloroform: Ethanol ((9.5:0.5) & 0.8 & 0.53 & 0.4 \\
\hline Ethanol & Chloroform: Ethanol ((8:2) & -- & -- & -- \\
\hline Water & $\begin{array}{l}\text { Benzene: Acetic acid: water (4: } \\
\text { 1.1:4.9) }\end{array}$ & -- & -- & -- \\
\hline
\end{tabular}

All spots in visible light were of yellowish brown color and UV spots of blue and fluorescent color. 
Shekokar S. S., International Journal of Ayurvedic\& Herbal Medicine 8(3) May.-June. 2018 (3223-3234)

Table 13: Atomic absorption spectrophotometry

\begin{tabular}{|l|l|l|}
\hline Sr.no. & Samples & Elements (concentration in ppm) Iron (Fe) \\
\hline 1. & Fresh juice (swaras) & 108.0 \\
\hline 2. & & \\
\hline 3. & Dry Powder (churna) & 211.84 \\
\hline 4. & Spray dry form (spray dry tablet) & 370.137 \\
\hline
\end{tabular}

Table 14: HPTLC analysis to determine content of wedelolactone

Markers used for comparison: wedelolactone, ecliptaalbasaponin I and ecliptaalbasaponin II

Ecliptaalbasaponin I and Ecliptaalbasaponin II could not be detected in all the samples of fresh juice, spray dry tablet, anukalpa swaras and anukalpa swaras ghan vati.

\begin{tabular}{|l|l|l|}
\hline Sr. no. & Samples (formulations) & Content in $\% \mathbf{w} / \mathbf{w}$ \\
\hline 1. & Fresh juice & 0.005 \\
\hline 2. & Dry powder & 0.25 \\
\hline 3. & Spray dry tablet & 0.014 \\
\hline 4. & Tablets & 0.023 \\
\hline
\end{tabular}

Table 15: HPLC analysisto determine content of wedelolactone by HPLC

Markers used for comparison: wedelolactone, ecliptaalbasaponin I and ecliptaalbasaponin II

Ecliptaalbasaponin I and ecliptaalbasaponin II could not be detected in all the samples of fresh juice, spray dry tablet, anukalpa Swaras and Anukalpa swaras ghan vati.

\begin{tabular}{|l|l|l|}
\hline Sr. No & Samples (formulations) & Content In \% W/W \\
\hline 1. & Fresh Juice & 0.007 \\
\hline 2. & Dry powder & 0.25 \\
\hline 3. & Spray dry tablet & 0.014 \\
\hline 4. & Tablet & 0.017 \\
\hline
\end{tabular}

\section{Phytochemical analysis}

Table 16: Preliminary qualitative analysis of alcoholic extract of powder of Bhringaraj for the presence of various functional groups

\begin{tabular}{clccc}
\hline Sr. & Reagent & Functional group & observation & Result \\
\hline 1 & Alcohol & Resins & Turbidity & absent \\
2 & Sodium bicarbonate & Saponin & Frothing & present \\
3 & Biurets test & Proteins & Yellow ppt & present \\
6 & Wagner's reagent & Alkaloids & Brown ppt & present \\
7 & Dragendroff's reagent & Alkaloids & Brown ppt & present \\
8 & Salkowinskii's reaction & Sterols & Green ppt & absent \\
9 & Liebermann's Buchard & Sterols & Green ppt & absent \\
10 & Dil. FeCl 3 Test & Tannin & Blue ppt & present \\
11 & Lead acetate test & Tannin & No ppt & present \\
12 & Benedict's reagent & Glycosides & Violet colour & present \\
13 & Fehling's reagent & Glycosides & ppt formation & present \\
14 & Neutral FeCl & phenols & Violet colour & present
\end{tabular}




\section{Discussion}

Sharangadharacharya had described that in the drug formulation, shushka form ${ }^{4}$ (dry but freshly collected and dried) should be taken in single quantity and while using the fresh drug or during the unavailability of the fresh drug, the green fresh plant drug should be taken twice in quantity to that of dry drug as the dry drug is guru and tikshna due to the lack of moisture and less concentration of chemical constituents ${ }^{44}$. This rule is applicable to all the drugs exceptfew enlisted ${ }^{45,46}$.Various dosage forms of Bhrungaraj panchanga i.e. ardra and shushka dosage forms were prepared; these were analyzed by various physicochemical and phytochemical tests. Ardra forms were prepared as, a) fresh juice and b) spray dried powder of fresh juice.Shushka forms were prepared as, a) anukalpa swaras from churna of shushka drug and b) ghan vati of anukalpa swaras.

\section{Physicochemical and phytochemical tests}

Various tests were appliedas per applicability of solid and liquid form and results were as follows- Foreign matter ${ }^{22}$ contentwas (table no 2) complying with Ayurvedic pharmacopoeia of India (API) standards. $\mathrm{pH}$ value ${ }^{23}$ of all the samples (table no 3) was in the range of 4-4.5. Swelling index ${ }^{24}$ of Bhrungaraj churna and spray dry drug was not significant as the drug was not having any mucilage content (table no 4). The test for foaming inde ${ }^{25}$ suggestive of saponin content was $>100$ in all samples and the saponin test (foam test) was found positive for all samples suggesting that Bhrungaraj churna was having some saponin content (table no.6).Percentage of moisture content ${ }^{26}$ (table no 5) for Bhrungarajchurna and spray dry drug complied the API standards for churna.Colorimetry (test for determination of optical density) ${ }^{27}$ showed optical density of the fresh swaras was more (0.41) than the anukalpa swaras $(0.25)$ indicating that the fresh juice was more concentrated than the anukalpa swaras (table no.7).Extractive values ${ }^{28}$ of Bhrungarajchurna and Bhrungaraj spray dry powder were evaluated - Alcohol soluble extractive value for Bhrungarajchurna, 9.8 $\%$, was not less than 5 percent which complied the API standards and for the spray dry powder it was 12.5. The aqueous extractive value for Bhrungaraj churna was $26.00 \%$ which was not less than 15 percent described in API, so it complied the API standards and for the spray dry powder it was $26.6 \%$.Other extractives such as Methanol extractive, Petroleum ether soluble extractive value, Benzene soluble extractive value were also evaluated.(table no 8)From the above observations, it was clear that solubility of Bhrungaraj churna and spray dry form was more in water, than other solvents.

Test for determination of ash value ${ }^{29}$ revealed that total ash value of Bhrungaraj churna was 14.4 which was not more than 22 percent, thus complied the API standards. (table no.9)

Acid insoluble ash of Bhrungaraj churna was 2.4 which was not more than 11 percent and thus complied the API standards and acid insoluble ash value of Bhrungaraj spray dry powder was 1.7.Water soluble ash of Bhrungaraj churna was 12.4 and total ash value of Bhrungaraj spray dry powder was 3.2.

It was observed that ash values of Bhrungaraj churna was more than the ash values of Bhrungaraj spray dry powder, all the values of churna complied the API standards.

Refractive index test suggestive of uniformity of solvent (oils, liquids, etc.), thickness or thinness and admixture was evaluated (table no 10) for freshly prepared swaras which was 1.3434 and that of anukalpa swaras was 1.33 . Refractive index for both the solvents was nearly same which showed their similar texture or thinness and homogeneity.

Spectrophotometry analysis ${ }^{30}$ showed common peaks at $220 \mathrm{~nm}, 330 \mathrm{~nm}$ in all the samples at the absorbance of 1.750 and 1.000 respectively. (table no 11). Thin layer chromatography ${ }^{31}$ was carried out using various mobile phases, the spots were observed in UV chamber and Rf (factor of retention) values were calculated. (table no.12) 


\section{Shekokar S. S., International Journal of Ayurvedic\& Herbal Medicine 8(3) May.-June. 2018 (3223-3234)}

a. Petroleum ether extract of Bhrungaraj churna and spray dry powder using mobile phase, benzene:chloroform (1:1) showed similar spots of Rf value, 0.02 in visible light (200-400nm).

b. Benzene extract and Chloroform extractof Bhrungaraj churna and spray dry powder using mobile phase, chloroform:ethanol ((9.5:0.5) showed spots of Rf value, 0.8 (visible light), 0.53 (UV) and 0.42 (iodine chamber)and many other phases were tried.

Separation of constituents of Eclipta alba Hassk. was found maximum in chloroform and benzene extract using the mobile phase of chloroform: ethanol (9.5:0.5). Spots of TLC using wedelolactone were similar in both Bhrungaraj churna and spray dry drug but spots using Ecliptaalbasaponin I and II could not be detected. Atomic absorption spectrophotometry ${ }^{32}$ analysis determined that the iron content was- freshswaras- 108.0 ppm elemental iron, churna- 211.84 ppm, spray dried tablet- 370.137 ppm, anukalpa swaras ghan vati3060 ppm. (table no.13) The anukalpa swaras ghan vati determined that iron content was 10 times more as compared to the spray dry drug, churna and fresh swaras of Bhrungaraj. In the process of spray drying the fresh juice was exposed to high temperature and high pressure while passing through the chambers, the exposure to heat might have affected the iron content in the spray dry drug.

The fresh juice is dilute due to the presence of water contentwhile Bhrungaraj anukalpa swaras ghan vati was prepared by processing of adding water to churna and boiling until the preparation of paste like thick slurry form to make tablets. So, evaporation of moisture, might have increased the iron content in anukalpa ghan vati as compared to churna.

High performance thin layer chromatography ${ }^{33}$ was carried out taking all the four formulations (table no 14) against the above mentioned three markers and the observations were as follows, content of wedelolactone was only identified and the other markers used i.e. ecliptaalbasaponin I and ecliptaalbasaponin II were not detected in the HPTLC analysis. Percentage of wedelolactone was also maximum in churna and minimum in the fresh swaras.

High performance liquid chromatography ${ }^{34}$ carried out for all four samples against three markers (table no 15). Wedelolactone content was nearly similar to that of the results obtained by HPTLC. The Ecliptaalbasaponin I and Ecliptaalbasaponin II could not be obtained in all the four samples or formulations. The Wedelolactone is the important active coumestan derivative of Eclipta alba. Percentage of Wedelolactone was found more in the Bhrungaraj churna $(0.25 \% \mathrm{w} / \mathrm{w})$, anukalpa swaras ghan vati $(0.017 \% \mathrm{w} / \mathrm{w})$ and comparatively less in spray dry powder ghan vati $(0.014 \% \mathrm{w} / \mathrm{w})$ and fresh juice $(0.007 \% \mathrm{w} / \mathrm{w})$.

The concentration of this constituent might be more in the dried state (churna) than in fresh juice and in spray dry powder ghan vati form. As per the reference of Sharangdhar Samhita dry drug is guru in guna and tikshna due to the lack of moisture and its tikshna guna may be due to the increased concentration of its active constituents in dry state.

The stability of wedelolactone might be more in dried form than in the fresh or wet form, so this may be the reason for more percentage of wedelolactone in churna than in fresh juice. Moreover, the spray dry drug was prepared by passing the fresh juice through hot air under pressure while churna is prepared by shade drying of raw material and then grinding. The processing in hot air may have altered the wedelolactone content of the drug in spray dried form.

\section{Causes of changes in phytochemical and physicochemical studies:}

The possible reasons might be, during the spray drying procedure, fresh juice was directly exposed to heat and so the active constituents may have evaporated during the direct heating process. In Bhavprakash Nighantu, Acharya KC Chunekar ${ }^{47}$ had described to use fresh swaras of Bhrungaraj and no heating to be done as the active chemical constituents may get evaporated due to exposure to heat. 


\section{Shekokar S. S., International Journal of Ayurvedic\& Herbal Medicine 8(3) May.-June. 2018 (3223-3234)}

All the ardra and shushkaformulations or dosage forms were evaluated for their physicochemical and phytochemical studies which studies revealed that there was little quantitative difference in the contents of the drugs in HPLC and HPTLC peaks and absorption spectrums (in Wedelolactone content), but atomic absorption spectrophotometry analysis revealed that elemental iron content was found more in the anukalpa swaras tablet form (shushka form)as compared tothe spray dry tablet (ardra form).

\section{Conclusion}

Present study revealed that shushka form of Bhrungaraj i.e. anukalpa swaras ghan vati had more percentage of wedelolactone and Iron content as compared to spray dried swaras tablet i.e. the ardra form of Bhrungaraj in double dose in iron deficiency anemia. So, the concept of using shushka drug twice in quantity to that of ardra drug to obtain equivalent results or contents was not observed in this study.

\section{Limitations/recommendations}

1. As swaras was difficult to prepare and restore for longer duration spray dried swaras was used in which the fresh juice is directly exposed to high temperature under high pressure to convert into powder form. This process could have caused variation in results.

2. HPTLC analysis were carried out by dissolving the formulations in different solvents. So, the concentration of the chemical constituents may differ due to different solubilities. So, the activity of Bhrungaraj swaras has to be further explored.

\section{REFERENCES}

1. Mosihuzzaman M, Choudhary M I. Standardization of herbal medicine, IUPCA. 2008. Pure and Applied Chemistry; 80. 2195-30.

2. Hill AF. Economic Botany, A textbook of useful plants and plant products. $2^{\text {nd }}$ Edi. New York: McGraw-Hill Book Company Inc; 1952.

3. Bucar et al. 2013; Jones and Kinghorn, Discovery and resupply of pharmacologically active plantderived natural products: A review, Biotechnol 2015.

4. Parashar R. Sharangadhar Samhita, Purva Khanda, 1/47. $3^{\text {rd } E d i . ~ N a g p u r: 1984: ~ B a i d y n a t h ~}$ publication; p.16.

5. Dixit SP, Achar MP. J. Sci. Res. Pl. Med., Vol-2. Study of Bhringaraj therapy in jaundice inchildren.1981. p. 96-100.

6. Wagner H, Fessler B. Planta Med., Vol- 52. In vitro 5- Lipoxygenase inhibition by Eclipta alba extracts and the coumestan derivative wedelolactone. 1986. p. 374-77.

7. Upadhyay RK, Pandey MB, Jha RN \& Pandey VB, J. Asian. Nat. Prod. Res., Vol- 3. Eclalbatin a triterpene saponin from Eclipta alba. 2001. p. 213-17. (Jadhav et al, 2009, Khare, 2004) Eclipta alba (L.).

8. Jadhav VM et al. Journal of Pharmacy Research, 2(8). Eclipta alba Linn - "Kesharaja': A Review. 2009. p. 1236-41.

9. Mehra PN, Handa SS. Pharmacognosy of Bhringraja antihepatotoxic drug of Indian origin. Indian J Pharm. Volume 30, 1968, p 284

10. Neeraja P V, Margaret E. IJCPR, Eclipta alba (L.) Hassk: A Valuable Medicinal herb. November 2011-January 2012. 2(4). p. 188-197.

11. Chunekar K C, Pandey G S. Bhavprakash Nighantu, Guduchyadi Varga, Shlokaa no. 240-241. Varanasi: Chaukhamba Vishvabharati Publication; 2002. p. 429.

12. Sharma P V, Sharma G. Dhanvantari nighantu, Karveeradi varga, $4 / 10-11.4^{\text {th }}$ Edi. ssssVaranasi: Chaukhamba orientalia publication; 2005. p .122-23. 


\section{Shekokar S. S., International Journal of Ayurvedic\& Herbal Medicine 8(3) May.-June. 2018 (3223-3234)}

13. Tripathi I. Raj Nighantu, Shatadvhadi varga. $2^{\text {nd }}$ Edi. Varanasi: Chaukhamda Krushnadasa academy; 2006. p. 89.

14. Sharma P V, Sharma G. Kaiyadeva nighantu, Oshadhi varga, 1/ 1573-75. $1^{\text {st }}$ Edi. Varanasi: Chaukhamba orientalia publication; 1979. p. 637.

15. Sharma A et al, Journal of Pharmacy Research, Pharmacognostic and Phytochemical Evaluation of roots of Eclipta alba and prostrata, 2011, 4 (6), 1673-1674.

16. Yadav P, Harisha CR, Prajapati PK. Journal of Current Pharmaceutical Research,Validation of pharmacopoeial characters ofBhringaraja (Eclipta alba Linn.)8 (1);2011.p.17-24.

17. Parashar R. Sharangadhar Samhita, Madhyam Khanda, Pratham adhyaya - 1/2. $3^{\text {rd }}$ Edi. Nagpur: Baidynath publication, Nagpur; 1984.p.125

18. Parashar R. Sharangadhar Samhita, Madhyam Khanda, Pratham adhyaya, 1/3-4. $3^{\text {rd }}$ Edi. Nagpur: Baidynath publication, Nagpur; 1984. p.125

19. Shastri PK, Chaturvedi GN. Charak Samhita,Uttaradha, Chikitsa sthana, Rasayan adhyaya, 1/2/12.Varanasi: Chaukhamba Bharti Academy; 1998. p. 27.

20. Vaidya Yadavji Trikamji Acharya, Siddha Yoga sangraha, Jwaradhikara, 6, Bidyanath Ayurved Bhavan, Nagpur, $9^{\text {th }}$ edition, 1990.p. 4.

21. Anandharamakrishnan C and Padma IS, Spray drying techniques for food ingredients encapsulation, $1^{\text {st }}$ edition. Wiley J and Sons publication.2015; IFT Press Book Spray drying techniques.p.1-36 and Amruta herbals Pvt.Ltd. Booklet for procedure of spray drying technique.

22. Namjoshi AN, Committee Chairman.The Ayurvedic Pharmacopoeia of India. Part-I, Vol. II, Tests and determinations. $1^{\text {st }} \mathrm{ed}$. New Delhi: The Controller of Publication, Government of India, Ministry of Health and Family Welfare, Publication Department, ISM and H; 2007. Appendix 2,2.2.2, Foreign matter, p. 159.

23. (138). Namjoshi AN, Committee Chairman. The Ayurvedic Pharmacopoeia of India. Part-I, Vol. II, Tests and determinations. $1^{\text {st }}$ ed. New Delhi: The Controller of Publication, Government of India, Ministry of Health and Family Welfare, Publication Department, ISM and H; 2007. Ph value, Appendix $3,3.3$, p. 213

24. Namjoshi AN, Committee Chairman. The Ayurvedic Pharmacopoeia of India. Part-II, Vol. I, Chemical tests and assays. $1^{\text {st }}$ ed. New Delhi: The Controller of Publication, Government of India, Ministry of Health and Family Welfare, Publication Department, ISM and H; 2007

25. Namjoshi AN, Committee Chairman. The Ayurvedic Pharmacopoeia of India. Part-II, Vol. I, Chemical tests and assays. $1^{\text {st }}$ ed. New Delhi: The Controller of Publication, Government of India, Ministry of Health and Family Welfare, Publication Department, ISM and H; 2007, Foaming index, appendix 2, 2.2.7

26. Namjoshi AN, Committee Chairman. The Ayurvedic Pharmacopoeia of India. Part-I, Vol. II Tests and determinations. $1^{\text {st }}$ ed. New Delhi: The Controller of Publication, Government of India, Ministry of Health and Family Welfare, Publication Department, ISM and H; 2007, Moisture content, Appendix 2, 2.2.10, p. 161.

27. Namjoshi AN, Committee Chairman.The Ayurvedic Pharmacopoeia of India. Part-I, Vol. II Tests and determinations. $1^{\text {st }}$ ed. New Delhi: The Controller of Publication, Government of India, Ministry of Health and Family Welfare, Publication Department, ISM and H; 2007, Colorimetry, appendix 2.2.6

28. Namjoshi AN, Committee Chairman.The Ayurvedic Pharmacopoeia of India. Part-I, Vol. II, Tests and determinations. $1^{\text {st }}$ ed. New Delhi: The Controller of Publication, Government of India, Ministry of Health and Family Welfare, Publication Department, ISM and H; 2007, Extractive values, Appendix 2, 2.2.7, p.160. 
Shekokar S. S., International Journal of Ayurvedic\& Herbal Medicine 8(3) May.-June. 2018 (3223-3234)

29. Namjoshi AN, Committee Chairman.The Ayurvedic Pharmacopoeia of India. Part-I, Vol. II , Tests and determinations. $1^{\text {st }}$ ed. New Delhi: The Controller of Publication, Government of India, Ministry of Health and Family Welfare, Publication Department, ISM and H; 2007, ash value, Appendix 2, 2.2.3, p. 160

30. Namjoshi AN, Committee Chairman.The Ayurvedic Pharmacopoeia of India. Part-I, Vol. II, Tests and determinations. $1^{\text {st }}$ ed. New Delhi: The Controller of Publication, Government of India, Ministry of Health and Family Welfare, Publication Department, ISM and H; 2007, spectrophotometry, appendix 2.2.5

31. Namjoshi AN, Committee Chairman. The Ayurvedic Pharmacopoeia of India. Part-I, Vol. IITests and determinations. $1^{\text {st }}$ ed. New Delhi: The Controller of Publication, Government of India, Ministry of Health and Family Welfare, Publication Department, ISM and H; 2007, chromatography, Appendix 2, 2.2.13, p. 164

32. Namjoshi AN, Committee Chairman. The Ayurvedic Pharmacopoeia of India. Part-I, Vol. II Tests and determinations. $1^{\text {st }}$ ed. New Delhi: The Controller of Publication, Government of India, Ministry of Health and Family Welfare, Publication Department, ISM and H; 2007, AAS, Appendix 2, 2.3.7, p.178.

33. Meier B and Spriano A. HPTLC, Standard operating procedures for HPTLC. Zurich University of Applied Sciences.International association for the advancement of High Performance Thin Layer Chromatography manual.p.1-2.

34. Standard operating procedures for HPLC, (https://garner.chem.wsu.edu.>2013/10)

35. Namjoshi AN, Committee Chairman.The Ayurvedic Pharmacopoeia of India. Part-I, Vol. IITests and determinations. $1^{\text {st }}$ ed. New Delhi: The Controller of Publication, Government of India, Ministry of Health and Family Welfare, Publication Department, ISM and H; 2007, TANIN, Appendix 5, 5.1.2, p. 239.

36. Namjoshi AN. Committee Chairman.The Ayurvedic Pharmacopoeia of India. Part-II, Vol. I, Chemical tests and assays. $1^{\text {st }}$ ed. New Delhi: The Controller of Publication, Government of India, Ministry of Health and Family Welfare, Publication Department, ISM and H; 2007, RESIN

37. Namjoshi AN. Committee Chairman.The Ayurvedic Pharmacopoeia of India, Part-II, Vol. I, Chemical tests and assays. $1^{\text {st }}$ ed. New Delhi: The Controller of Publication, Government of India, Ministry of Health and Family Welfare, Publication Department, ISM and H; 2007, SAPONIN

38. Namjoshi AN. Committee Chairman. The Ayurvedic Pharmacopoeia of India. Part-II, Vol. I Chemical tests and assays. $1^{\text {st }}$ ed. New Delhi: The Controller of Publication, Government of India, Ministry of Health and Family Welfare, Publication Department, ISM and H; 2007, GLYCOSIDE

39. Namjoshi AN. Committee Chairman. The Ayurvedic Pharmacopoeia of India. Part-I, Vol. II, Tests and determinations. $1^{\text {st }}$ ed. New Delhi: The Controller of Publication, Government of India, Ministry of Health and Family Welfare, Publication Department, ISM and H; 2007, Protein, appendix 2, 2.2.17, p.147.

40. Namjoshi AN. Committee Chairman. The Ayurvedic Pharmacopoeia of India. Part-II, Vol. I Chemical tests and assays. $1^{\text {st }}$ ed. New Delhi: The Controller of Publication, Government of India, Ministry of Health and Family Welfare, Publication Department, ISM and H; 2007, Sterol

41. Namjoshi AN, Committee Chairman. The Ayurvedic Pharmacopoeia of India. Part-II, Vol. I, Chemical tests and assays. $1^{\text {st }}$ ed. New Delhi: The Controller of Publication, Government of India, Ministry of Health and Family Welfare, Publication Department, ISM and H; 2007, amino acid

42. Namjoshi AN, Committee Chairman. The Ayurvedic Pharmacopoeia of India. Part-I, Vol. II,Tests and determinations. $1^{\text {st }}$ ed. New Delhi: The Controller of Publication, Government of India, Ministry of Health and Family Welfare, Publication Department, ISM and H; 2007, alkaloid, Appendix 2, 2.2.18, p. 147. 
Shekokar S. S., International Journal of Ayurvedic\& Herbal Medicine 8(3) May.-June. 2018 (3223-3234)

43. Namjoshi AN, Committee Chairman. The Ayurvedic Pharmacopoeia of India. Part-I, Vol. II, Tests and determinations. $1^{\text {st }}$ ed. New Delhi: The Controller of Publication, Government of India, Ministry of Health and Family Welfare, Publication Department, ISM and H; 2007, Starch, Appendix 2, 2.2.14, p.146.

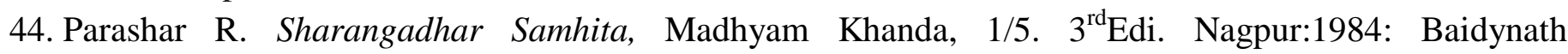
publication; p.126.

45. Sen GD, Edited by Mishra S., Manaparibhasha, Bheshajya ratnavaali, 2005, Chaukhamba Surbharti Publication, $1^{\text {st }}$ edition, Cha. 2/ 22, 23, p. 23)

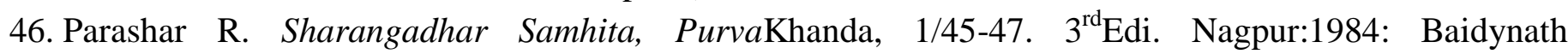
publication.p. 16

47. Chunekar K C, Pandey G S. Bhavprakash Nighantu, Guduchyadi Varga, Vimarsha. (commentry). Varanasi: Chaukhamba Vishvabharati Publication; 2002. p. 429-431

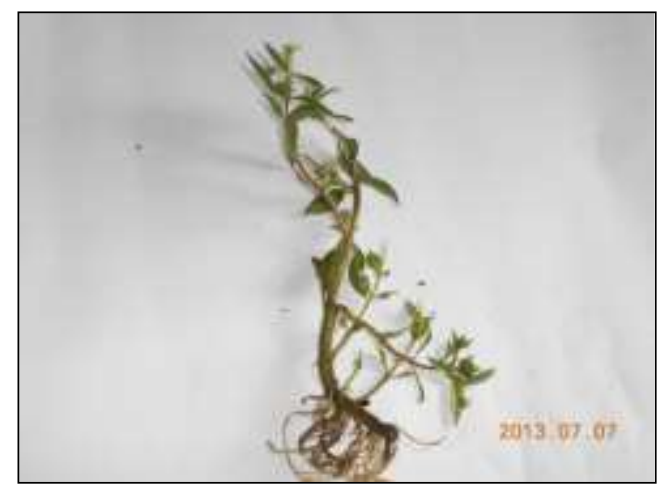

Figure 1: Entire plant of Bhrungaraj

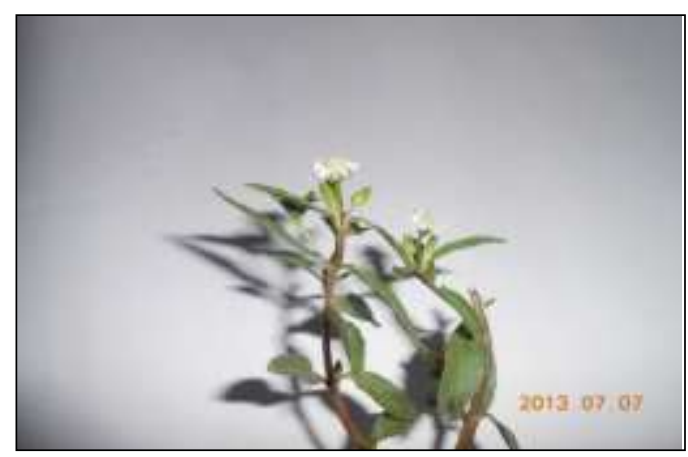

Figure 2: Inflorescence

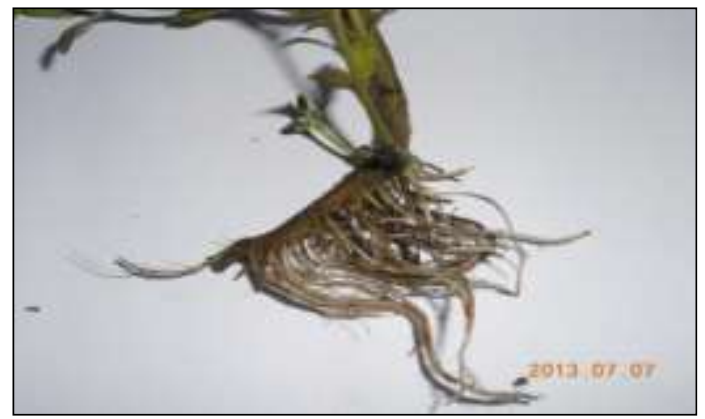

Figure 3: Root of Eclipta

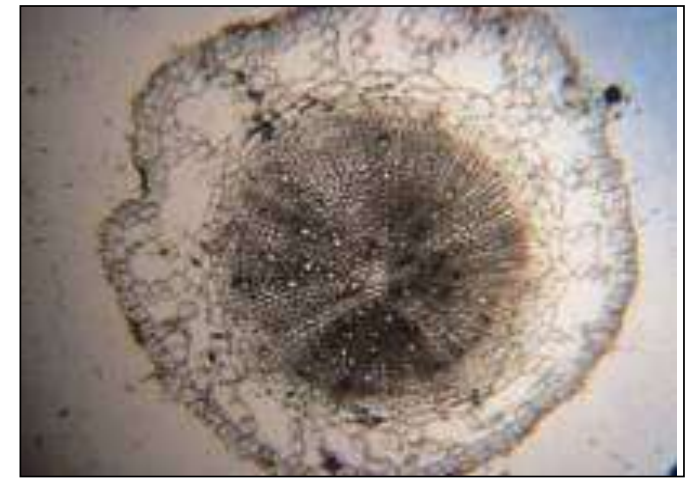

Figure 4: Root TS of Eclipta

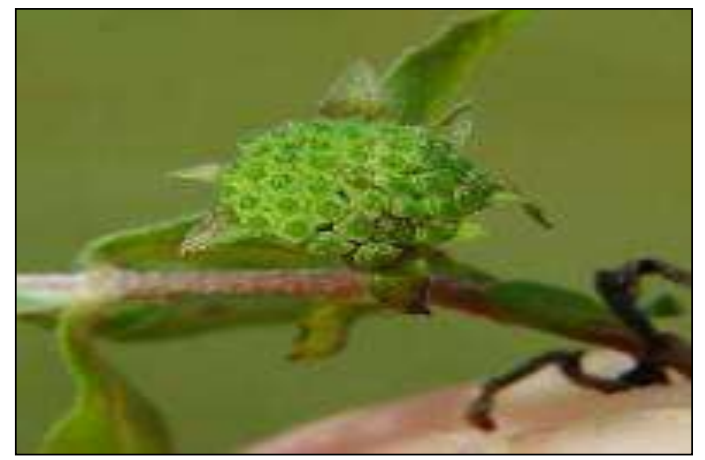

Figure 5: Eclipta Flower

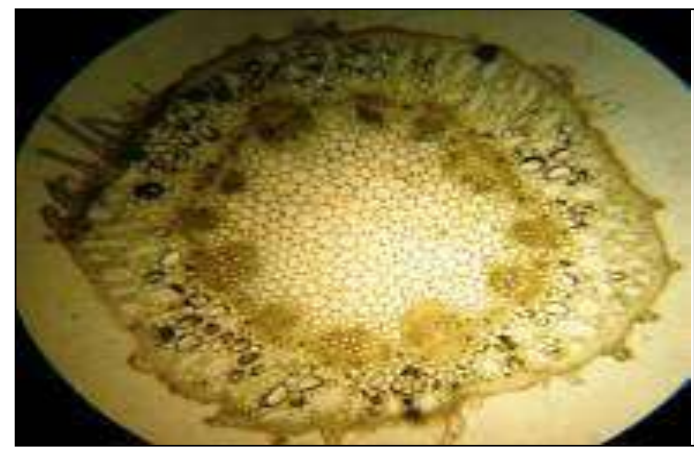

Figure 6: T. S. of stem 